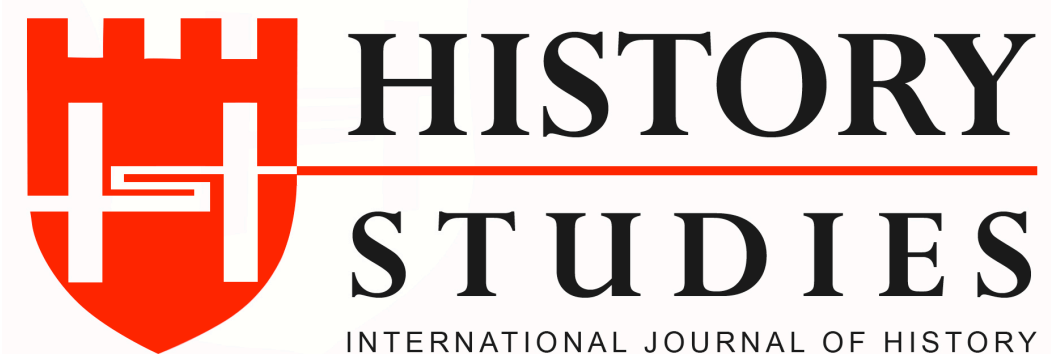

ISSN: 13094173 (Online) 1309 - 4688 (Print)

Volume 11 Issue 6, December 2019

DOI Number: 10.9737/hist.2019.813

Araştırma Makalesi

Makalenin Geliş Tarihi: 14.10.2019 Kabul Tarihi: 25.10.2019

Atıf Künyesi: Seyfettin Kaya, “Ortaçağ Arap-İslam Devletlerinde İlm-i Nücum ve Müneccimlik”, History Studies, 11/6, Aralık 2019, s. 2311-2324.

\title{
ORTAÇA $\breve{G}$ ARAP-ISLAM DEVLETLERINDE ILM-İ NÜCUM VE MÜNECCIMLIK
}

\author{
Ilm-i Nujûm and Munejjimness in Medieval Arab-Islamic States
}

\author{
Dr. Seyfettin Kaya \\ ORCID No: 0000-0003-2181-5973 \\ Siirt Üniversitesi
}

\begin{abstract}
Öz: Kehanette bulunma arzusu ve astroloji eski çağlardan beri milletlerin ve uygarlıkların yakından takip ettikleri bir olgu olmuştur. İlkçağlardan beri kullanılan astroloji ile ilgili kavramlar, fetih hareketleri sonucunda Arap-İslam Devleti'nde daha da ilgi çekmeye başlamıştır. İslam dini ve $\mathrm{Hz}$ Peygamber tarafından kesin bir şekilde yasaklandığı ifade edilmesine karşın, geleceği merak etme düşüncesi ve insani zafiyetlerden dolayı Müslüman toplumda ve İslam devletlerinin yönetici sınıfı arasında gelecek ile ilgili kehanet ve astroloji varlığını sürdürmüştür. Özellikle, Abbasilerde ve Orta Çağ İslam dünyasında var olan diğer Arap devletleri ilm-i nücûma (astroloji) ilgi göstermişlerdir. Abbasiler (750-1258), Fatımiler (909-1171) ve Endülüs Emevileri (756-1031) dönemlerinde devlet sarayında farklı zamanlarda ve farklı hükümdarlar tarafından birçok müneccim görevlendirilmiştir. Abbasi döneminde, Ebu Maşer ve İbn Nevbaht, Fatımiler döneminde İbn Yunus ve Endülüs Emevileri döneminde İbn Ishâk ve Mesleme el-Mecrîtî öne çıkmışlardır. Hatta zaman zaman hükümdarlar müneccimlere danışarak karar alırlardı; bir savaşa veya barışa müneccimlere danışmadan karar verilmezdi.
\end{abstract}

Anahtar Kelimeler: Astroloji, Müneccimlik, İlm-i nücûm, Abbasiler, Fatımids

\begin{abstract}
The desire to prophesy and astrology has been closely followed by nations and civilizations since ancient times. As a result of the conquest movements, the concepts related to astrology, which has been used since ancient times, have began to gained more attention in the Arab-Islamic State. Although it was stated that by Islamic religion and the Prophet was strictly prohibited, prophecy and astrology continued in the Muslim society and among the ruling class of the Islamic states due to the thought of the future and human weaknesses. In particular, the Abbasids and other Arab states that existed in the medieval Islamic world showed an interest in ilm-i nücûm (astrology). During the Abbasid (750-1258), In the Fatımids (909-1171) and Andalusian Umayyad (756-1031) periods, many munejjim were appointed by the rulers of the state palace at different times. Abu Masser and Ibn Nevbaht in Abbasid Period and Ibn Yunus in the Fatımids Period and Ibn Ishaq and Mesleme alMecritî came to the fore during the Andalusian Umayyads Period. Even, from time to time the rulers would make decisions in consultation with astrologers; a war or peace decision would not be taken without consulting them.
\end{abstract}

Key Words: Astrology, Munejjimness, Ilm-i nujûm, Abbasids, Fatımids

\section{Giriş}

İnsanoğlu, eski çağlardan beri geleceği merak etme arzusu taşıdığı için kehanet ve astrolojiye ilgi duymuştur. Çeşitli toplumlarda ve kültürlerde bulunan insanlar, müneccimler vasıtasıyla kehanetlere başvurarak gelecekten haber almak ve bu haberler doğrultusunda alınması gereken tedbirlere başvurmak için yoğun bir çaba içerisine göstermişlerdir. Musevi 
tarihçilerine göre astroloji Hz. Âdem'e vahiy yoluyla öğretilmişti ve insanlar büyük tufandan daha önceleri bilim, kültür, sanat ve özellikle astrolojiyi öğrenmişlerdi. Hz. İbrahim de astrolojiyi Kalde'de (Mezopotamya) öğrenmiş ve daha sonra Misırlılara öğretmiştir. Hz. Âdem, Hz. İbrahim'e İbranilerin geleceği ile ilgili konuşurken yıldızlara bakmasını istemiştir. Ancak astroloji ile ilgili bilgiler bu mistik rivayetlerle sınırlı değildir. Nitekim astroloji ve müneccimliğin kökenini M.Ö. IV bin yıllarına kadar götürenler de bulunmaktadır. Eski uygarlıklardan Mısır, Babil, Çin ve Kalde'de kehanette bulunmak ve insanlara gelecekten haber vermek amacı ile falcılar görev yapmışlardır. Falcılığa dair en eski örneklerin Mezopotamya'da olduğuna dair iddialar da bulunmaktadır. Mezopotamya'da astrolojinin Sümerler döneminde başlayan gelişimi Babiller döneminde devam etmiştir. $\mathrm{Bu}$ konuda bilgi veren en eski kaynaklardan biri Enuma Anu Enlil ${ }^{1}$ (MÖ.1700) isimli antik Babil tabletleridir. Bu tabletlerde Venüs'ün döngüsü ile ilgili bir takım kehanetlerde bulunulmaktadır. Bu tabletleri izleyen takribi kanıtlar Babillilerden kalma ay tutulmalarını gösteren tabletlerdir.

Kehanette bulunma ve astroloji çalışması yalnız siyasi güçler tarafından yürütülmemiştir. Aynı zamanda kişisel düzeyde astrolojik çalışmaların da olduğu görülmüştür. Kişisel astroloji ile ilgili sürece ne zaman geçildiğine ilişkin kesin bir bilgi bulunmamaktadır. Ancak yine de bunun Mezopotamya'da benimsenmiş olması kuvvetle muhtemeldir. Babil bölgesi M.Ö. 539'larda Persler tarafından ele geçirilmiş ve Zerdüştlüğün tesirinde kalan Babil'de metafizik kapsamına giren konularda bazı bakış açılarının, bazı yaklaşımların bir değişim sürecinden geçtiği görülmüştür. Bu süreçten kehanet ve astroloji de etkilenmiş ve her insanın ayrı bir "birey", ayrı bir "evren" olduğu görüşü daha bir ön plana çıkarak, kişisel doğum haritası kavramı astrolojik literatüre girmiştir. Bu metafizik unsurlar sıkça Batı dünyası tarafından yıllarca kullanılmıştır. Yaklaşık M.S. 600'lü yılların başına kadar, astrolojik üstünlük batı dünyasının elinde bulunmuş, çok büyük gelişmeler olmasa da çalışmalar sürekli devam etmiştir. VIII. yüzyıldan itibaren üstünlük doğu dünyasına kaymış, XIII. yüzyılla kadar batıda fazlaca gelişme olmamıştır. Ancak İslamiyet'le birlikte Araplar her alanda öne çıkmışlardır. Özellikle matematik alanda yaptıkları çalışmalarla, bugün bile kullandığımız Arap noktaları gibi bazı özel uygulamaları geliştirmişlerdir. Maşa'allah b. Eserî, Eb̂̂ Maşer, Ya'kub b. Kindî gibi Arap astrologlar da çeşitli dönemlerde yaşamışlar, günümüze ulaşan eserler yazmışlardır.

\section{1. İlm-i Nücum (Astroloji) Kavramı}

İslâm bilim literatüründe, "ilm-i ahkâm-ı nücûm", "slnaat-i ahkâm-ı nücûm" veya kısaca "ilm-i nücûm", "ahkâm-ı nücûm", "ilm-i hey'et", "ilm-i eflak" diye ifade edilen astroloji vel astronomi, XIX. yüzyıla kadar tek bir bilim dalı olarak kabul edilmiştir. İslam uygarlığında hem astrologlar hem de astronomlar "müneccim" kelimesiyle ifade edilmiştir. Bu anlayış Osmanlı Devleti döneminde (1299-1918) de değişmemiş ve olduğu gibi devam etmiştir. ${ }^{2}$ Nitekim Kâtip Çelebi (ö. 1659), ünlü eseri “Keşfü'z-zünûn'da” bu konuya değinmiş ve ilm-i nücûmun üç peryottan meydana geldiğini açılamıştır. Bu peryotlardan ilk ikisinin astronomi;

\footnotetext{
${ }^{1}$ Erken astroloji, Asurlar, Babiller veya Akadlar dönemine aittir. Bu dönemden itibaren Kral Ashurbanipal'in emri altında da uygulanmasina rağmen orijinal hali M.Ö. II. bin yılına tarihlenen "Enuma Anu Enlil" adında eski bir alâmet dizisi astrolojinin en temel dayanaklarından biri olmuştur. Astrolojinin ilk zamanlarında farklı işaretler aracıllğılyla tahminler yapıldı. Örneğin güneş tutulması çok önemlidir. Asur döneminde, tutulmalar neticesinde tahminler erkenden yapılabiliyordu. Çok sayıda Asur astrolog tutulma tabletlerini ayrıntılı bir şekilde inceleyerek gizliliği esas alarak sundukları bir rapor ile tahminlerini krala bildirirlerdi. Güneş tutulması tarafindan öngörülen talihsizliği komşu ülkeye atfetme bir gelenek haline gelmiştir. Bkz. Enn Kasak, Ancıent Astrology As A Common Root For Science And Pseudo-Science, Folklore, Vol. XV, Tartu 2000, s. 87.

${ }^{2}$ C. A. Nallino, “Astroloji”, $\dot{I} A$, c. I, MEB Yayınları, İstanbul 1978, s. 682; Salim Aydüz, İstanbul Muvakkithaneleri ve Muvakkitleri, İBB Yayınları, İstanbul-2009, s. 9.
} 
son ve üçüncü aşamanın astrolojinin veya ilm-i nücumun konusu olduğundan bahsetmektedir. ${ }^{3}$ $\mathrm{Bu}$ konuya değinen İbn-i Haldun, "yıldızların gökyüzündeki hareketlerinden, varlıkların etkilendiğini ve bunun sonucunda varlıkların birbiri karşısındaki durumlarından bir mizaç oluştuğunu ve bu mizacın havaya karıştığını, ilm-i nücûm işi ile uğraşan müneccimlerin sezgi yolu ile havanın etkisini gözetip tahminlerde bulunduğunu" dile getirmiştir. ${ }^{4} \mathrm{Bu}$ konudaki bilgilere Batı literatüründe de rastlanmaktadır. Nitekim Batlamyus, yıldızların doğal unsurlar üzerindeki etkilerinin gözlemlenmesinde oluşan doğal astroloji ve yıldızların insan kaderi üzerindeki etkilerinin gözlemlenmesinde oluşan yargısal astroloji olmak üzere ilm-i nücuтu iki kısma ayırmıştır. ${ }^{5}$ Temelde ilm-i ahkâm-ı nücûmun veya ilm-i hey'enin, ilm-i hey'e (astronomi) ile arasındaki fark, ilm-i nücumun yıldızların konum ve hareketlerinin bir işaret sistemi oluşturduğuna ve bu sistem sayesinde geçmiş, şimdiki durum ve geleceğe dair bilgi elde etmenin mümkün olduğuna inanılmasıdır; bu anlamda ilm-i nücûm astronominin metafiziğidir. Cahiliye döneminde bu bilim dalı Araplar tarafından yaygın bir şekilde kullanılmış ve bazı Araplar gökyüzündeki yıldızlara tapmışlardır. ${ }^{6}$ Bu konu gelecek ile kehanetlerde bulunulan "mel-hame" adlı kitaplarda da ele alınmıştır. Mel-hamelerin en meşhuru Hz. Danyel'e istinat edilen kitaptır. Bu kitapta $\mathrm{Hz}$. Danyel'in bildirdiği kehanetler ve müneccimlik hakkında bilgi veren kitapta, Hıristiyan Takvimi, Kıpti Takvimi ve Arap Takvimine göre olası yeryüzü olaylarının olabileceği bilgisine yer verilmiştir. ${ }^{7}$

\section{2. İlm-i Nücumun Arap-İslam Devletlerinde Ortaya Çıkışı}

İlm-i nücûma ait ilk kaynakların antik Mezopotamya ve Mısır'a ait olduğunu yukarıda da ifade etmiştik. Ancak ikinci, üçüncü ve dördüncü aşamadaki kaynaklar İslam dünyasını doğrudan etkileyen unsurlar olacaktır. İkinci aşamada Eski Araplar, doğum sırasında gözlenen işaret ve olaylardan aldıkları portreleri çıkardılar ancak yıldızlara açıkça atıfta bulunmadan bunları fal ile ilgili söylemlerle dile getirmeye çalıştılar. Bu dönemde yeni doğanın burcunu çizme uygulaması köklü bir gelenek haline geldi. Üçüncü aşamada Arap astrologlar veya müneccimler tarafından Yunan, Helen ve Romalılara ait kaynaklar Arapçaya çevrilmiştir. Dördüncü aşamada ise Sasanilerden kalma bazı kaynakların Arapçaya çevrilmesi yer almaktadır. Böylece Roma ve Helen İmparatorluklarının, orijinal Pehlevi metinlerinin Müslüman Araplar tarafindan revize edilmesi Araplar arasında ilm-i nücumun gelişimine zemin oluşturdu. ${ }^{8}$

Cahiliye Dönemi Arapları ilm-i nücûma büyük bir ilgi göstermişlerdir. Araplar geleceklerini öğrenmek ve gaipten haber almak için yaygın bir şekilde ilm-i nücûma başvurmuşlardır. Ancak bu tavır İslamiyet'in özüne ters düştüğü için ilm-i nücûm ve yıldızlara tapınmak $\mathrm{Hz}$. Muhammed tarafından şiddetle yasaklanmıştır. ${ }^{9}$ Tüm bu yasaklamalara rağmen Emeviler döneminde (661-750) Müslümanların ilm-i nücûm ile ilgili kaynakları Arapçaya çevirmelerine şahit olmaktayız. Emeviler hanedanına mensup Hâlid b. Yezîd (ö. 102/720 civarında) Batlamyus'un "Kitâbü's Semere" adlı astrolojik eserini Arapçaya tercüme ettirdi. ${ }^{10}$ Abbasiler döneminde (750-1258) saray astroloğu olarak görev yapan Ebu Mấşer "Halîd b. Yezîd'in

\footnotetext{
${ }^{3}$ Kâtip Çelebi, Keşfu'z-Zunun, c. II, nşr. M. Şerafeddin Yaltkaya, Maarif Vekâleti, İstanbul 1943, s. 1930-1931; Salim Aydüz, "Osmanlı Devleti'nde Müneccimbaşllık", Osmanlı Bilim Araştırmaları Dergisi, Sayı:1, 1955, İstanbul 1995, s.159; Salim Aydüz, a.g.e., s. 9.

${ }^{4}$ İbn-i Haldûn, Mukaddime, c. I, Çev: Halil Kendir, Yeni Şafak Kültür Armağanı, İstanbul 2004, s. 148.

${ }^{5}$ Toufic Fahd, "Nudjûm", $E L^{2}$ (İng.), vol. VIII, Leiden 1995, s. 105-108.

${ }^{6}$ Tevfik Fehd, "İlm-i Ahkâm-1 Nücum", DİA, TDV Yayınları, c. XXII, İstanbul- 2000, s. 124-126.

${ }^{7}$ Toufic Fahd, La Divination Arabe, Universite de Strasbourg, Leiden 1966, s. 408.

${ }^{8}$ Toufic Fahd, "Nudjûm", VIII, s. 105-108.

${ }^{9}$ Tevfik Fehd, "İlm-i Ahkâm-1 Nücum", XXII, s. 124-126.

${ }^{10}$ Ali Bakkal, "İ̀sâm Astronomi Tarihinde İbn Rüşd: Büyük İslâm Filozofu İbn-i Rüşd”, Diyanet Dergisi, c. XLVIII, Sa. 3, Temmuz-Ağustos-Eylül 2013, s. 198.
} 
astroloji ile uğraştı̆̆ını, bu alanda bir eser yazdĭ̆ını ve bu eserin tanınmış astrolojik eserlerden biri olduğunu" ifade etmiştir. ${ }^{11}$

Abbasiler döneminde (750-1258) ise tercüme hareketleri yaygınlaşmış ve ilm-i nücûma dair yeni kaynaklar Müslümanlar tarafından kullanılmaya başlanmıştır. İlm-i nücûm, Abbasi halifesi Me'mûn döneminde (813 - 833) önemli bir gelișme göstermiștir. Bu alanda Hintliler tarafından yazılan "Siddhanta"; Sâsâniler tarafindan yazılan "Zîc-i Şâĥ̀" (Zî̀-i Şehriyâr) ve Misır'da yaşayan Yunanlı Batlamyus'un "Tetrabiblos" adlı yapıtları Arapçaya tercüme edilmiştir. Abbasiler döneminde (750-1258) saray astroloğu veya müneccim olarak görev yapan Maşa'allah b. Eserî, Eb̂̂ Mâşer ve sonrasında Harezmî bu yapitlardan önemli ölçüde istifade etmişlerdir. $^{12}$ Muhtemelen Abbasi halifesi Me'mûn döneminde (813-833) kurulan Beytü'lHikme kurumundaki tercüme faaliyetlerinin artmasına paralel olarak ilm-i nücûma ait eserlerin Arapçaya tercümesi de hızlanmıştır. I. Şâpûr döneminde (240-272) Pehleviceye çevrilen Hellenistik Dönem (M.Ö. 323- M.S. 30) astroloğu Dorotheus Sidon'a ait hekzametreler ${ }^{13}$ (Carmen Astrologicum) Ömer b. Feruhhân et-Taberî (ö. 815) tarafından Arapçaya çevrilmiştir. ${ }^{14}$ Sasani kralı I. Anuşirvan (531-579) tarafından Pehlevi diline çevrilen Roma İmparatorlar1 Hadrianus (MS 117 - MS 138) ve Antoninus Pius (M.S. 138-M.S. 161) döneminin önemli bir astroloğu Vettius Valens'e ait Antoloji eseri, bu dönemde Arapçaya çevrilmiş ve ilm-i nücûm erbabı Araplar tarafından kullanılmıștır. Ayrıca yine Sasanilerden kalma "Zerdüşt Fi'l - Nücûm Vata" adlı kaynak Arapçaya çevrilmiştir. Nitekim Illm-i nücûma ait Sanskritçe eserler İran'da da popülerdi. Birçoğu Perslere ait ilk İslami ilm-i nücûm kitaplarına çok sayıda Hint teorisi dâhil edilmişti. Bunların çoğu Pehleviceden Arapçaya tercüme edilmiştir. Böylece Roma ve Helen İmparatorluklarının, orijinal Pehlevi metinlerinin Müslüman Araplar tarafından revize edilmesi ilm-i nücûmun Araplar arasında gelişimine zemin oluşturdu. ${ }^{15}$

\section{Emeviler ve Abbasilerde İlm-i Nücûm ve Müneccimlik}

Ortaçağ Arap toplumunda Hz. Muhammed döneminde (571-632) Kuran-1 Kerim'in yasaklamasından dolayı müneccimliğe pek rastlanmamıştır. İslam'ın bu ilmi yasaklaması, akaid ve fikıh âlimleri ile filozofların ilm-i nücûmu boş ve manasız olarak değerlendirmesine yol açmıştır. İslam toplumunda ilm-i nücûmun pratik hayata uygulanmasını engellemiştir. ${ }^{16}$ Ancak Emeviler döneminde (661-750) başlayan çeviri hareketleri ilm-i nücûma olan ilgiyi yeniden canlandırmıştır. Emeviler zamanının ünlü müneccimi Tufeyl Rumi, "İslam milletinin, büyük kıranın süresi kadar, yani 960 sene devam edeceğini, bu milletin başlangıcında olduğu gibi kıran tekrar akrep burcuna dönüp, gezegenlerin konumları değişince, ümmetin işlerinin bozulacağını veya tahminlerin aksine her şeyin yeniden başlayacağını" ifade etmiştir. ${ }^{17}$

Abbasiler döneminde (750-1258) tercüme faaliyetleri olgunlaşmış ve ilm-i nücûma bağlı olarak müneccimlik ortaya çıkmıştır. Abbasi halifeleri müneccimleri sarayda istihdam etmiş ve önemli olayların akışını müneccimlerden öğrenmeye çalışmışlardır. Abbasilerin ikinci halifesi olan Mansûr zamanında (754-775) hız kazanan tercüme hareketleri sırasında ilm-i nücûma duyulan ilgi artmıştır. Bu döneminde öne çıkan müneccimlerin başında Eb̂̂ Sehl b. Nevbaht yer almaktadır. Halife Mansur'un iktidarının sonlarına doğru öldüğü düşünülen babasının

\footnotetext{
${ }^{11}$ Fuat Sezgin, İslam 'da Bilim ve Teknik, c. I, T.C. Kültür ve Turizm Bakanlığı Yayınları, İstanbul, 2008, s. 4.

12 Zeki Tez, Ortaçă̆ İslam Dünyasında Bilim ve Teknik, Dicle Üniversitesi Fen-Edebiyat Fakültesi Yayınları, Diyarbakır 1991, s. 80-81.

${ }^{13}$ Gök cisimleri ve yıldızların konumlarını gösteren tablolarından oluşan astrolojik içerikli ölçümlerindir.

${ }_{15}^{14}$ D. Pingree, “Astronomy and Astrology in India and Iran”, ISIS, LIV (1963), s. 241-242.

${ }^{15}$ Toufic Fahd, "Nudjûm”, VIII, s. 105-108.

${ }^{16}$ Salim Aydüz, a.g.. $\bar{m}$., s.162

${ }^{17}$ İbn-i Haldûn, a.g.e., s. 442.
} 
yerine baş müneccim olan $E b u$ Sehl $b$. Nevbaht, halifenin güvendiği kişilerden biri haline gelerek 775 yılında onunla birlikte Mekke'ye hac yapmaya gitmiştir. ${ }^{18}$ Halife Mansur'un çok nüfuzlu saray müneccimi olan İbn Nevbaht, Bağdat şehrinin kuruluşunda yapılması gereken astronomi hesaplarını Maşa 'allah b. Eserî ile birlikte görev almıştır. ${ }^{19}$ Hatta Halife Mansur' dan sonra başa geçen el-Mehdi (775-785), el-Hadi ((785-786)) ve Hârûn er-Reşîd (786-809) dönemlerinde her işte kendisine danışılmasını sağlamış ve bütün müneccimlerin başı olarak görev yapmış ilk kişi olmuştur. ${ }^{20}$

Abbasiler döneminde ilm-i nücûm erbabı yalnız sarayda istihdam edilmemiştir. Bu işle uğraşanlar müneccimlerin savaşlara katılmaları sağlanmıştır. Bu iddiamıza en güzel örneğe Mehdi döneminde (775-785) rastlamaktayız. Mehdi döneminde (775-785), oğlu Hârûn erReşîd' in katıldığı bir savaşa müneccimlerin de katıldığı görülmüştür. Nitekim bu savaşa katılan müneccimlerden biri Abbasi Devleti'nin (750-1258) başına istikbalde gelecek olaylar hakkında bilgiler vermiş ve Halife Mehdi'nin iktidarının 20 yıl süreceğine değinmiştir. Ancak Halife Mehdi'nin hoşuna gitmeyeceği düşünülen bu bilgi hükümdardan saklanmaya çalış1lmıştır. ${ }^{21}$

Abbasiler öneminde (750-1258) hilafet sarayında müneccimlerin en çok görüldüğü dönem Halife Me'mûn Dönemi (813-833) olmuştur. Halife Me'mun dönemde (813-833) Maşa'allah b. Eserî, Mûsâ b. Şâkir ve Yahyâ b. Eb̂̂u Mansûr gibi isimler saray müneccimi olarak öne çıkmışlardır. Bu dönemde ilm-i nücûm ile ilgili kaynakların Arapçaya çevrilmesi önem kazanmıştır. Sasanilerde güçlü ve kadim bir ilm-i nücûm geleneğinin bulunmas1, Abbasi sarayında İran kökenli müneccimlerin çalışmasına ortam oluşturmuştur. Bunların başında gelen kişilerden biri de Ömer b. Ferruhân et-Taberî' dir. Bu konuda İbnu'l-Kıftî önemli bilgiler vermektedir. İbnu'l-Klftî ve Sâid el-Endelüsî, “Ömer b. Ferruhân et-Taberî̀nin, ilm-i nücûm ve bu ilmin hükümleri konusunda döneminin en iyilerinden biri olduğunu" ifade etmiştir. ${ }^{22}$ Yine Halife Me'mun döneminde (813-833) müneccim olarak çalışan kişiden biri Mâşâllah $b$. Eserî̀'dir. Aslen bir Yahudi olan Mâşâllah b. Eserî, 762 yılında Bağdat'ın kuruluşunda şehrin konumunun ve koordinatlarının belirlenmesi için yapılan çalışmalarda görev almış ve Halife Me'mûn'un sarayında müneccim olarak çalışmıştır. Ancak Halife Me'mûn'un iktidarının ilk yıllarında 815 yılında hayatını kaybetmiştir. ${ }^{23}$ Halife Me'mûn döneminde (813-833) Abbasi sarayında çalışan kişilerden diğer birinin Mûsâ b. Şâkir olduğu ifade edilmektedir. Gençlik yıllarında Horasan'a bağlı Merv bölgesinde eşkiyalık ve haydutluk yapan Musa b. Sâkir, zamanla Halife Me 'mun'un yanında ünlü bir müneccim haline gelecektir. ${ }^{24}$ Musa b. Sâkir' in bu duruma gelmesi şu şekilde hülasa edilmektedir; veliahtllğg döneminde Abbasi veliahtı Me'mûn ile Horasan bölgesinde bulanan Merv'de (809-813) yakın dostluk ilişkileri kuran Musa b. Sâkir, 813 yılında Me'mûn'un Halife olması üzerine üç oğlu ile beraber Bağdat'a gelerek onun himayesinde yaşamaya başlamıştır. Illm-i nücûm işi ile meşgul olduğu için bir süre sonra "elmüneccim" adıyla anılmaya başlamıştır. ${ }^{25}$ Mûsâ b. Şâkir'in oğulları Muhammed, Ahmed ve

\footnotetext{
${ }^{18}$ Cengiz Aydın, "Ebû Sehl b. Nevbaht”, DİA, TDV Yayınları, c. X, İstanbul-1994, s. 228.

${ }^{19}$ George Saliba, "The Role Of The Astrologer In Medieval Islamıc Society", Bulletin D'études Orientales, T. 44, Sciences Occultes Et Islam (1992), s. 65; Ari Belenkiy, "Mâshâ'allâh ibn Atharî (Sâriya)", The Biographical Encyclopedia of Astronomers, Vol. II, Editor-in-Chief Thomas Hockey, Springer, New York 2007, s. 740-741.

${ }^{20}$ Zeki Tez, a.g.e., s. 90.

${ }^{21}$ İbn-i Haldûn, a.g.e., s. 443.

22 İbnu'l-Kıftî, Târîhu'l-Hukemâ', nşr. Julius Lippert, Dieterich'sche Verlagsbuchhandlung, Leipzig 1903, s. 241242; Sâid el-Endelüsî, Tabakatü'l Ümem, Nşr. Louis Rizkullah Şeyho, Beyrut-1912, s. 55; İlhan Kutluer, “TABERÎ, Ömer b. Ferruhân”, DİA, TDV Yayınları, c. XXXIX, İstanbul-2009, s.321

${ }^{23}$ Fuat Sezgin, GAS, VII, Institut für Geschichte der Naturwissenschaften, Leiden 1979, s. 103.

${ }^{24}$ Josep Casulleras, "Banû Mûsâ", The Biographical Encyclopedia of Astronomers, Vol. I, Editor-in-Chief Thomas Hockey, Springer, New York 2007, s. 92.

${ }^{25}$ Kazım Çeçen-Atilla Bir, "Beni Musa”, DİA, TDV Yayınları, c. V, İstanbul-1992, s.450.
} 
Hasan "Benî Musa" (Musa'nın Oğulları) diye anılmışlardır. Halife Me'mûn'un yakın arkadaşı olan Musa b. Şakir, zamanla öldükten sonra Benî Mûsâ kardeşler Halife Me'mûn'un himayesine girmiş ve yaptıkları çalışmalarla ona hizmet etmişlerdir. ${ }^{26}$ Yine bu dönemde Abbasi sarayında çalışan diğer bir kişi Yahyâ b. Eb̂̂u Mansûr (ö. 845) olacaktır. Abbasi halifesi Me'mûn'un sarayında baş müneccimliğe kadar yükselecektir. ${ }^{27}$ İran kökenliydi ve asıl adı Firûzân'ın oğlu Bizîst idi. Babası Abbasilerin ikinci halifesi Mansur'un hizmetinde çalışan bir müneccimdi. Bundan dolayı Yahyâ'nın gençliği Bağdat'ta geçmişti. İlk bilinen pozisyonu Halife Me'mun'un veziri el-Fadl $b$. Sehl için müneccimlik yapmaktı. Ancak vezir el-Fadl $b$. Sehl, 818 Şubatında öldürülünce, İslamiyet'i kabul ederek Arapça bir isim olan "Yahyâ" adını almıştır. Zamanla Halife Me'mun'un yakın arkadaşı oldu ve onun için çeşitli durumlarda astrolojik tahminlerde bulundu. ${ }^{28}$ Yaşamının büyük çoğunluğunu müneccimlik yaparak geçirmiş ve yıldızların yerini tespit ederek onlardan bir takım anlamlar çıkarmaya (kehanet) çalışmıştır. Yahyâ b. Eb̂̂u Mansûr'un 845 y1lında ölümünden sonra kendi nesebinden gelen ve yine müneccimlik işi yapan torunlarına Benü'l-Müneccim (Âlü'l-Müneccim) adı verilmiştir. Bu nesil Abbâsî halifelerinin koruyuculuğunda faaliyet göstermiş, müneccim olarak etkinlik sürdürmüşlerdir. ${ }^{29} \mathrm{Bu}$ konuda öne çıkan isim Harun $b$. Ali $b$. Yahya $b$. Mansur el müneccim olmuştur. İbn Hallikan "Yahya b. Ebu Mansur el-Müneccim'un torunu olan Harun b. Ali b. Yahya b. Mansur el müneccim 'in, Abbasi sarayında müneccimlik yaptığına; hafizlık, şairlik ve sosyal nitelikleri ile çok iyi bir bilgin olduğuna" vurgu yapmıştır. ${ }^{30}$ Öte yandan Halife Me 'mun döneminde etkinlik gösteren müneccimlerin hepsinin erkek olduğunu söylemek yanlış olur. Bu dönemde faaliyet gösteren kişilerden biri de kadın bir kâhinedir. Bu kadın kâhine belki Abbasi sarayında müneccime olarak resmi bir görev almamıştır. Ancak zaman zaman halifenin talihine bakıp kendisine kehanetleri ile ilgili haberler göndermiştir. Nitekim bunu Abbasi hanedan üyeleri olan el-Emin ile Me'mun arasında yaşanan taht kavgasında görmekteyiz. El-Emin ile $M e^{\prime} m u n$ arasındaki taht kavgası sırasında Me 'mun'un yanında yer alarak Horasan'da el-Emin ile mücadele ettiği sırada, örneğine pek rastlanmayan kadın bir kâhine olan Hasan $b$. Sahl b. Nevbaht'ın kızı Bevrân ve Me'mun'un eşi arasında geçen bir diyalog dikkat çekmektedir. Buna göre, Me'mun'un eşi, kadın bir kâhine olan Bevrân'a "usturlabı kaldır ve kocamın burcuna bak" şeklinde bir talepte bulunmuştur. Bevrân da talihine baktığı Me'mun'un "tahta bir alet ile başına bir kötülük geldiğini” gördü. Bu haberi babası vasıtasıyla sarayda bulunan Me'mun'a çabucak yetiştirdi. Belirlenen zamanla Me'mun'un herhangi bir ahşabın yanına gelmesi sağlandı. Bu sırada Me 'mun'un hizmetkârı kendisine tarak ve diş temizleyici getirdi. El-Hasan, hizmetçiye Me'mun'a bunları vermeden önce kendisinin kullanmasını emretti. Hizmetçi ahşap tarak ile saçını taramaya başladı, bir süre sonra hizmetçinin başı şişti ve hizmetçi hayatını kaybetti. Bu olaya şahit olan Me'mun, el-Hasan'1 hizmetine geri aldı. Ödül olarak Bevrân'a köylerinin geri verilmesini sağladı. Bu işte parmağı olduğu düşünülen Vezir İbn Zeyyât'ın (ö. 847) mallarına el konuldu. ${ }^{31}$

Abbasiler döneminde yine Me'mun zamanında saray müneccimlerinden biri olarak gösterilen kişilerin başında $Y a^{\prime} k \hat{u} b \quad b$. İshak el-Kindî gelmektedir. 801 yılında doğan ve

${ }^{26}$ Donald Hill, A History Of Engineering In Classical And Medieval Times, Routledge, London-Newyork-2007, s. 339.

${ }^{27}$ Sâid el-Endelüsî, a.g.e., 1912, s. 50; Said El-Endülüsi, Tabakatü'l-Ümem, (Çev: Ramazan Şeşen), Türkiye Yazma Eserleri Başkanlığı Yayınları, İstanbul-2014, s. 142.

${ }^{28}$ Benno van Dalen, "Yahyâ ibn Abî Mansûr: Abû "Alî Yahyâ ibn Abî Mansûr al-Munajjim", The Biographical Encyclopedia of Astronomers, Vol. II, Editor-in-Chief Thomas Hockey, Springer, New York 2007, s. 1249-1250.

${ }^{29}$ Yavuz Unat, "Yahya b. Ebu Mansur el-Müneccim”, DİA, TDV Yayınlar1, c. XLIII, İstanbul-2013, s.242.

${ }^{30}$ Ibn Hallikan, Vefeyatü'l-A 'yan, c. III, Translated: Baron Mac-Guckin de Slane, Mektebetu Lübnan (Librairie du Liban), Beyrut 1970. s. 604.

31 George Saliba, a.g.m., s. 65. 
“Arapların filozofu” olarak bilinen Ya'kûb b. İshak el-Kindî, Halife Me'mun (813-833), Halife Mu'tasım (833-842), el-Vâsık (842-847) ve el-Mütevekkil (847-861) dönemlerinde Abbasi sarayı ile ilişkilendirilmektedir. Eski Yunan bilim ve felsefesinin özümsemesi ve benimsenmesinde Arap dünyasında en önemli rolü oynayan $Y a^{\prime} k u \hat{b} b$ b. İshak el-Kindî, seleflerinin felsefi ve teolojik konumlarda "dünyanın sonsuz olduğu" tezini eleştirerek, yazdığ eserlerle bu düşünceyi çürütmeye çalıșmıștır. ${ }^{32} Y a^{\prime} k \hat{u} b$ b. Ishak el-Kindî yalnız felsefi ve teolojik konularla değil, aynı zamanda ilm-i nücûm ve müneccimlik konularına da ilgi göstermiştir. IX. yüzyıl âlimlerinden biri ile arasında geçtiği rivayet edilen bir olay, elKindî̀nin ilm-i nücûm ve müneccimlik müessesesi ile ilgilendiği iddiamızı desteklemektedir. Nizâmî 'Arûzî̀'nin kaydettiği rivayete göre olay şu şekilde gelişmiştir;

\begin{abstract}
“Aslen Yahudi kökenli olan Ya'kûb b. İshak el-Kindî, bir gün Halife Memün'un huzuruna gelerek Islam Imamlarından üstün birinin yanına oturdu. O İmam Ya'kûb'a 'Sen Yahudi birisisin. Neden İslam Imamlarından üstün birinin yanına oturdun?' diye sordu. Ya'kûb, "senin bildiğini ben (de) bilirim, benim bildiğimi sen bilmezsin" şeklinde cevap verdi. O İmam Ya'kûb'u müneccim olarak tanırdl, Ancak onun diğer ilimleri bildiğinden haberi yoktu. Bu cevaba bozulan imam Ya'kûb'a 'bir kâ̆ğt parçasına bir şey yazacă̆ım, ĕger sen ne yazdı̆̆ımı bilirsen, sana inanırım.' Sonra şöyle bahse girdiler: 'İmam Ya'kûb b. İshak'a iddiayı kazanması halinde ona bir redâ̂ (önü açık düğmesiz uzun elbise) vereceğini vaad ederken; Ya'kûb b. İshak ise iddiayı kazanması halinde imama bir katır ve bin dinar değerinde ve sarayın önünde olan bir bina vereceğini' ilan etti. Sonra imam bir kâğıt parçasının üzerine bir șey yazarak Halife Me'mun'un döseğinin altına biraktı. Kendisine sıra gelen Ya'kûb b. İshak, toprak bir levha istedi, kalktt, yüksekliği ölçtü ve talihini hazırladı. Yıldız falını toprak levhanın üstünde karıştırdl. Yıldızlart tespit ederek sabitledi. Gizli ve saklı şartlarl yerine getirdi. Daha sonra Halife Me'mun'a dönerek söyle dedi; 'Ya Emîr'ul-Mü'minin. O kâğldın üzerinde yazılmış olanın ilki bitki, sonuncusu hayvan olmuştur.' Me'mun döşeğin altına elini uzatarak kâğıdı aldı ve çıkardı. Imam oraya "Musa'nın asası" yazmıştı. Halife Me'mun çok şaşırdı, İmam hayretlere düştü. Böylece iddiayı Ya'kûb b. İshak kazanmış oldu. "33
\end{abstract}

$Y a$ 'kûb b. İshak Kindî̀nin Halife Me'mun dönemindeki (813-833) icraatları ve kehanetleri

bununla sınırlı değildir. O sırada kendisini himaye eden Abbasi halifesi Me'mun'dan bile çekinmeyerek Abbasi Devleti'nin akıbeti hakkında korkunç tahminlerde ve kehanetlerde bulunmuştur. İslam toplumunun durumuna ilișkin kıranlarla ilgili bir kitap yazan $Y a{ }^{\prime} k u \hat{b} b$. İshak Kindî, bu kitaba Cafer Sadık'a istinaden "EŞ-Şiatu Bi'l-Cefr" (Cefir'in Yardımcısı) adını koymuştur. Bu kitapta el-Kindî, "Abbasilerin gelecekte başına gelecek musibetlerden söz etmiş, Hicri 7. Yüzyllın ortalarında Bağdat'ın işgal ve istila edileceğini ve Abbasilerin çöküşünü, İslam toplumunun çöküşü ve dağllmasının izleyeceğini" söylemiştir. El-Kindî̀nin yazdığı bu kitabın varlığı günümüze ulaşmadı. Muhtemelen Bağdat'ın işgali ve istilası sonrasında İlhanlı hükümdarı Hülağü Han (1256-1265) tarafından Dicle nehrine atılan kitaplar arasında yer almıştır. $^{34}$

IX. yüzyılda Abbasi sarayında Halife Me'mun'un yanında müneccim olarak çalışan son kişi Sanad b. Ali adı ile bilinen bir Yahudi'dir. Bağdat'ta çalışan ve Abbasi sarayında müşterileri bulunan Yahudi bir müneccimin oğluydu. Kendisi de Bağdat'ta aktif bir şekilde matematik ve astronomi alanlarında çalışmıştı. Bir süre sonra Halife Me'mun için müneccim olarak çalıştı. Zamanla halifenin etkisi ile İslamiyet'i kabul etmiști. ${ }^{35}$

\footnotetext{
32 Jon Mc Ginnıs \& David C. Reisman, Classical Arabıc Phılosophy: An Anthology of Sources, Hackett Publishing Company, Indianapolis/Cambridge 2007, s. 1.

${ }^{33}$ Nizâmî 'Arûzî Semerkandî, a.g.e., 1327, s. 88-89; Nizâmî 'Arûzî Semerkandî, a.g.e., 2016, s. 76-77; Şehrezurî ve Beyhakî, el-Kindî'nin Yahudi olduğunu ve zamanla İslamiyet'i kabul ettiğini vurgulamaktadır. Bkz. Zahireddin Ali bin el-Beyhakî, Itmam Tetimmat Şivan el-Hikme, Lahor 1351, s. 25-26; Şemseddîn es-Şehrezurî, Nüzhetü'l-Ervâh, Çev: Eşref Altaş, Türkiye Yazma Eserler Kurumu Başkanlığ 1 , İstanbul 2015, s. 690.

${ }^{34}$ İbn-i Haldûn, a.g.e., s. 442-443.

35 Sonja Brentjes, "Sanad ibn "Alî: Abû al-Tayyib Sanad ibn "Alî al-Yahûdî", The Biographical Encyclopedia of Astronomers, Vol. II, Editor-in-Chief Thomas Hockey, Springer, New York 2007, s. 1011.
}

\title{
History Studies
}


Abbasiler döneminde müneccimlerin saray ahalisi içinde görüldüğü bir diğer süreç ise Mû'tezîd dönemindedir (892-902). Bu dönemde dikkat çeken müneccimlerden biri Sâbit $b$. Kurra'dır. Abbasi sarayında müneccim olarak görev yapacak olan Sâbit b. Kurra, gençlik yıllarında Harran'da sarraflık yapmış, zamanla bu sanatını terk ederek Bağdat'a gelmiş; matematik, astronomi ve doğa bilimleri tahsil ederek kısa zamanda büyük bir şöhret kazanmıștır. Bir rivayete göre, Bağdat'ta Muhammed b. Mûsâ b. Sâkir'in eğitim halkasında bulunmuş ve hocası tarafından Halife Mu'tazıd'ın huzuruna çıkarılmış ve bu halifenin özel müneccimleri arasına girmiştir. Diğer bir rivayete göre ise Halife Muvaffak-billah, oğlu Mu'tazıd'a hiddet ederek onu hapse attığ 1 sirada, Sâbit b. Kurra'yı da onun hizmet ve refakatine tayin etmiştir. Bu sırada Sabit b. Kurra'yı yakından tanıyan Mû'tezîd hilafet makamına geçince onu halife sarayına müneccim olarak almıştır. ${ }^{36}$

Abbasi halifesi Mu'temid (870-892) ve Mû'tezîd (892-902) dönemlerinde ise Ebû Ma'şer elBelhî sarayda müneccim olarak görev almışlardır. 100 yaşına kadar yaşayan Ebû Ma'şer Bağdat Abbasi sarayının en büyük astroloğu olarak kabul edilmektedir. ${ }^{37} 47$ yaşına kadar hadis ilmiyle meşgul olan Ebû Ma 'şer el-Belhî Horasan'dan ayrılarak Bağdat'a gelmiş, Abbâsî halifesi Mu 'temid-Alellah'ın kardeşi ve ikinci veliahdı Muvaffak'ın hizmetine girmiş, sonunda çağının en büyük müneccimi (astroloğu) olmuştur. İlkçağ ve Ortaçağ düşünce anlayışına göre

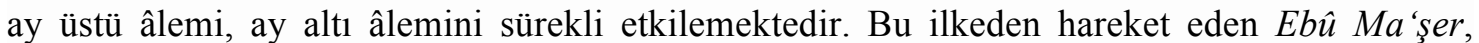
astronominin verilerine dayanarak ilm-i nücûmu temellendirmeye çalışmıştır. Ona göre "zamanı belirleyen ve mevsimlerin meydana gelmesini sağlayan ylldızlar elbette ki her şahsin ahlâk, karakter ve psikolojik yaptsl üzerinde de etkili olacaktır" ${ }^{38}$ Nizâmî 'Arûzî'nin kaydettiğine göre Ebû Ma 'şer'in ilm-i nücûmla ilgilenmesi Ya'kûb b. İshak el-Kindî ile yaşadığ 1 rivayet edilen şu olaydan sonra başlamıştır. Şöyle ki;

\begin{abstract}
"Taassup bilginlerinden olan Belh fikıhçılarından bir fikıhçı, bir bıçak aldı, bir astroloji kitabının arasına bıraktı, Bağdat'a gidip ve Ya'kûb b. İshak'ın dersinde oyalanarak, sonra bir anda onu öldürmek için firsat kollamaya başladı. Bu amaçla ev ev dolașıp, sonunda Bağdat'a ulaștı ve hamama gitti. Dışarı çıktı, temiz elbiselerini giydi, o kitabı yolda bıraktı ve Ya'kûb b. İshak'ın sarayına yöneldi. Sarayın kapısına varınca, sarayın kapısında duran altın koșumlu birçok eșek gördü. Ne Hașim oğullarından ne de Bă̆dat meşhurları ve diğer ünlülere rastladı ve uğradl. Ya'kûb'un önündeki halkaya girdi ve methederek şöyle dedi: 'Mevlana hakkında astroloji ilminden bir şey okumak istiyorum.' Ya'kûb b. İshak, şu şekilde cevap verdi. 'Sen doğu tarafindan beni öldürmek için gelmişsin, astroloji ilmi okumak için değil. Fakat pişman olmuşsun, astroloji okuyacaksın, o ilimde kemale ereceksin, Muhammed (S.A.V) ümmetinde büyük müneccimlerinden biri sen olacaksin.'

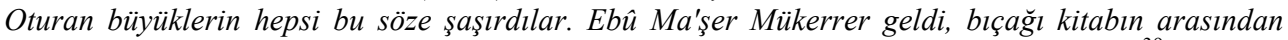
çıkardı, kırıp, attı ve eğildi. 15 yıl ĕgitim gördü, astroloji ilminde ulaştı̆̆ı o dereceye vard. ${ }^{39}$
\end{abstract}

Diğer taraftan Batı lireratüründe de Eb̂ิ $M a$ 'şer ile ilgili bilgilere yer verilmiştir. Bu konuda George Saliba'nın verdiği bilgiler kayda değerdir. George Saliba, "Ebû Ma'şer' in hapishanede bulunan Abbasi hanedan üyesi Mû'tezîd'i ziyaret ettiğini ve ona, üzerine yazı yazarak verdiği bir kumaş parçasında birkaç savaş ve mücadeleden sonra halife olacağını müjdelediğini ve bu

\footnotetext{
${ }^{36}$ İbnü'l Kıfti, a.g.e., s. 115; İbn Ebi Usaybia, Uyûnu'l-Enbâ' Fi Tabakati'l-Atibbâ', c. I, Kahire 1956, s. 215-216; Salih Zeki, Âsâr-ı Bâkiye, Çev: Melek Dosay Gökdoğan-Remzi Demir-Mutlu Kılıç, c. III, Babil Yayın Dağıtım, Ankara-2004, s.74; Ali Bakkal, Harran Okulu, Şanlıurfa Valiliği İl Kültür ve Turizm Müdürlüğü Yayınları, İstanbul 2006, s. 84.

${ }^{37}$ Keiji Yamamoto, “Abû Ma'shar Ja'far ibn Muhammad ibn 'Umar al-Balkhi”, The Biographical Encyclopedia of Astronomers, Vol. I, Editor-in-Chief Thomas Hockey, Springer, New York 2007, s. 11; Ebu Ma'şer'in Bağdat Abbasi sarayında çalıştı̆̆ına dair bilgilere Feganî’nin eserinde de rastlanmaktadır. Bkz. El Fergânî, Cevami İlm En-Nucüm ve Usul-El Harekât (Astronominin Özeti ve Göğ̈̈n Hareketlerinin Esaslarl, (Çev: Yavuz Unat), T.C. Kültür ve Turizm Bakanlığı Yayınları, Ankara, 2012, s. 14.

${ }^{38}$ Muammer Dizer, "Ebu Ma'şer el-Belhi”, DİA, TDV Yayınları, c. X, İstanbul-1994, s. 182.

${ }^{39}$ Nizâmî 'Arûzî Semerkandî, Çehar Makale, Tashih: Muhammed Kazvinî ve Muhammed Muin, Tahran 1327, s. 88-89; Nizâmî ‘Arûzî Semerkandî, Çehâr Makâle, Demavend Yayınları, İstanbul 2016, s. 77-78.
}

\title{
History Studies
}

HISTORY ST UDIES 
tahminin zamanla gerçekleştiğini, bunun üzerine halife olan Mû'tezîd'in, Ebû Ma'şer'e 'Seni unutmadım ve tahminin gerçekleşti, Sana ayda 100 dinar ödenek ve emlakta otuz (nazlan) veriyorum ve ben seni halifelikteki baş astroloğum yaptyorum ve sana derhal 1000 dinar armă̆an verilsin' dediğini" dile getirmiştir. ${ }^{40}$

\section{Fatımilerde İlm-i Nücûm ve Müneccimlik}

Arap-İslam devletlerinde özellikle Emeviler döneminde (661-750) başlayan ilm-i nücûm ve müneccimlik hareketleri Abbasiler döneminde (750-1258) yaygınlaşmıştı. Bu faaliyetler Abbasilerden koparak yeni bir güç haline gelen Fatımiler (909-1171) ve Endülüs Emevi Devleti (756-1031) dönemlerinde de görülmüştür.

Fatımî halifelerinin astronomi ve astroloji ilimlerine özel ilgi gösterdikleri tahmin edilmektedir. Bu konuda bilgiler veren İbn Hallikan, Fatımilerin dördüncü halifesi MuizLidînillâh'n (953-975) "son derece zeki, kararl, yüce fikirli, başarılı bir bilgin olduğunu ve astronomi-astrolojiye ilgi duyduğunu" ifade etmiştir. ${ }^{41}$ Nitekim Kahire şehrinin kuruluşu esnasında ilm-i nücûm erbabı müneccimlerin toplandığı ve şehrin kurulması gereken yere inşa edildiği sırada ve şehre "Kahire" adının verilmesinin nedenleri arasında bir yıldız isminin olduğu ifade edilmektedir. Fatımi halifesi Muiz-Lidînillâh (953-975) günümüzdeki Kahire dolaylarının fethine ünlü komutanı Cevher es-Sikıllı’ yi (ö. 992) göndermiştir. Cevher es-Sikullî bölgeyi ele geçirdikten sonra burada bir şehrin kurulması için ilm-i nücûm erbabı olan müneccimleri çağırarak "yıldızın kova burcunda doğduğu sırada temel atılmasını ve temelin etrafinda bulunan direklere asılı bir şekilde bulunan iplerdeki zillerin çalması ile harekete geçilmesi gerektiğini" söylemiştir. Fakat zillerin asılı bulunduğu iplere kargaların konması üzerine yıldızın Merih (Kahir) burcunda olduğu sırada askerler işaretin geldiğini sanarak ellerinde bulunan taşları temellere atmaya başlamaları hazırlanan temel atma planını alt üst etmiştir. Zira askerlerin temele taş atmaya başladıkları vaktin uygunsuzluğundan yakınan müneccimler "eyvah! Merih (Kahir) yıldızı doğarken taşlar temellere atıldı" demișlerdir. Böylece Merih (Kahir) yıldızı doğarken taşlar temellere atıldığı gerekçesi ile kurulan şehre Kahire adı verilmiştir. ${ }^{42}$

Fatımi halifeleri arasında özellikle el-Hâkim Biemrillah'ın (996-1021) astronomiye karşı özel bir ilgisinin olduğu bilinmektedir. ${ }^{43}$ Bir takım yasaklamaların yapıldığı ve halkın $i l m-i$ nücûm erbabına tepki gösterdiği bir sırada Halife el-Hâkim Biemrillah'ın (996-1021) emrinde çalışan bürokrasinin müneccimleri koruma altına aldığı görülmektedir. Bu konuda bilgi veren İbn Hallikan, "404/1013-1014 yıllarında ilm-i nücûm erbabının ülkeden kovulmasını isteyenlere karşı bu işle uğraşan müneccimlerin Kahire baş kadısına başvurarak haklarını savunduğunu ve Baş kadı Malik Ibn Said'in de haklı bulduğu müneccimleri sürgüne göndermediğini" dile getirmiştir. ${ }^{44}$ Halife el-Hâkim Biemrillah döneminde (996-1021) ilm-i nücûm konusunda tanınmış bilim insanlarına da rastlanmaktadır. İbn Yûnus (950-1009) Halife el-Hâkim Biemrillah döneminin ilm-i nücûm işi ile uğraştığı bilinen en önemli bilim insanlarından biridir. İbn Yûnus bir müneccim (astrolog) olarak ün yapmıştı. Astrolojik

\footnotetext{
${ }^{40}$ George Saliba, a.g.e., s. 67.

${ }^{41}$ Ibn Hallikan, a.g.e., III, s. 380.

42 Makrizî, İttiazü'l-Hunefa bi-Ahbari'l-Eimmeti'l-Fatımiyyine'l-Hulefa, Thk. Cemaleddin eş-Şeyyal, c. I. Kahire 1948, s. 159-160; Aydın Çelik, Fatımiler Döneminde Kahire Şehri, Fırat Üniversitesi Basımevi, Elazığ-2008, s. 11-12.

${ }^{43}$ Ibn Hallikan, a.g.e., II, s. 365-366; Aydın Çelik, a.g.e., s. 99.

${ }^{44}$ Ibn Hallikan, a.g.e., III, s. 451.
} 
tahminlerde bulunmak ve doğru sonuçlara ulaşmak için bu işle çok zaman harcard1. ${ }^{45}$ Ancak İbn Yunus'un babası oğlunun bu işlerle meşgul olmasından çok hoşnut değildi. Bu konuda İbn Hacer el-Askalani, kıymetli bilgiler vermekteydi. İbn Hacer el-Askalani, babasının oğlu İbn Yunus'tan "O müneccim ve sâhir (sihirbaz) biridir. Ondan hadis bile rivayet edilmez." dediğini nakletmektedir. ${ }^{46}$ Muhtemelen babası, oğlu İbn Yunus'un ilm-i nücûm işi ile uğraşmasını ve zamanının çoğunu müneccimliğe ayırarak sihir işleriyle uğraşmasını tasvip etmemiş olmalıdır.

Fatımilerin dışında bu sırada Kuzey Afrika'da ilm-i nücûm ve müneccimlik konusunda öne çıkan isimlere de rastlamaktayız. Bunların başında gelen kişi İbn Bannâ olmuştur. Fas-Marakeş doğumlu olan İbn Bannâ, matematik ve astronomi alanlarında tanınmıştır. Marakeş’te en az 17 usta öğreticiden eğitim aldı. Ancak sık sık Marakeş yakınlarındaki bir yerleşim bölgesinde ikamet eden Ebî Abdullah el-Hazmîrî̀nin (ö. 1279) yanına giderek onun ders halkasına katıldı. Hocası el-Hazmîrî̀nin etkisi ile ilm-i nücûm ve müneccimlik ile ilgilendi. Daha sonra büyük bir olasılıkla Kuzey Afrika'da bulunan Merini sultanı Eb̂̂ Sâid'in (1309-1331) hizmetinde bir müneccim olarak çalışmış ve yaptığ1 astrolojik öngörülerle (kehanetlerle) ölümünden sonraki 10 yıl içinde gerçekleşen olayları bildiği iddia edilmiştir. ${ }^{47}$

\section{Endülüs Emevîlerinde İlm-i Nücûm ve Müneccimlik}

Ortaçağ Arap-İslam dünyasının doğusunda bulunan Abbasiler ve Fatımilerde ilm-i nücûm ve müneccimlik faaliyetleri görüldüğü gibi Arap-İslam dünyasının batısında bulunan Endülüs Emevilerinde de bu faaliyetlere rastlanmıştır. İspanya'da tanınmış bir müneccim olan İbn İshâk, aslen Tunus kökenliydi. İbn İshâk'ın dişında İspanya' da müneccimlik işlerine bakan bir diğer kişi İbn Ebû el-Ricâl el-Kayravânî ydi. ${ }^{48}$

Endülüs'te müneccimlik işi ile uğraştığına şahit olduğumuz son kişi Mesleme el-Mecrîtî idi. Büyük bir olasılıkla Endülüs Emevileri döneminde (756-1031) II. Hişam'ın (976-1009) sarayda görev almış olmalıdır. ${ }^{49}$ Gençlik yıllarında Endülüs Emevilerinin başkenti olan Kurtuba'ya gelmiş ve yaşamının sonlarına kadar burada tanınmış bir müneccim olarak yaşamıştır. ${ }^{50} 1006$ 1007 yıllarında gerçekleşen Satürn ve Jüpiter'in birleşimi ile de ilgilendi; bununla birlikte hanedan, harabe, katliam ve açlı̆̆ın değişimini önceden haber verdi. ${ }^{51}$ Mesleme el-Mecrîtî̀ ye ilm-i nücûm ve müneccimlik konusunda atfedilen ve 1009 yılında yazdığ 1 düşünülen en önemli eser "Rütbetü'l el-Hâkim" adlı kaynaktır. Bu kaynakla müneccimlik, astroloji ve büyü, gizli ilim konularını içeren meselelere değindiği ifade edilmektedir. ${ }^{52}$

${ }^{45}$ David A. King, "Ibn Yûnus: Abû al-Hasan "Alî ibn "Abd al-Rahmân ibn Ahmad ibn Yûnus al-Sadafî", The Biographical Encyclopedia of Astronomers, Vol. I, Editor-in-Chief Thomas Hockey, Springer, New York 2007, s. 573; Goldstein, B.R., "Ibn Yûnus", The Encyclopaedıa Of Islam, (EL $\left.{ }^{2}\right)$ (İng.), Vol. III, s. 969.

${ }^{46}$ İbn Hacer el-Askalani, Lisânü'l-Mîzân, c. IV, Beyrut 1390/1971, s. 232-233.

${ }^{47}$ Julio Samsó, "Ibn al-Bannâ': Abû al-'Abbâs Ahmad ibn Muhammad ibn 'Uthmân al-Azdî al-Marrâkushî", The Biographical Encyclopedia of Astronomers, Vol. I, Editor-in-Chief Thomas Hockey, Springer, New York 2007, s. 551-552.

48 Julio Samsó , "Ibn Ishâq: Abû al-“Abbâs ibn Ishâq al-Tamîmî al-Tûnisî”, The Biographical Encyclopedia of Astronomers, Vol. I, Editor-in-Chief Thomas Hockey, Springer, New York 2007, s. 558-559.

${ }^{49}$ Mehmet Özdemir, "Hişâm II", DİA, TDV Yayınları, c. XVIII, İstanbul 1998, s. 146-147.

${ }^{50}$ Kâtip Çelebi, Keşfu'z-Zunun, c. II, Arapçadan Tercüme Eden Rüştü Balcı, Tarih Vakfı Yurt Yayınları, İstanbul 2007, s. 567; J. Vernet, "al-Majrîtî", Dictıonary Of Scıentıfic Bıography, Vol. IX, Edıtor In Chief: Charles Coulston Gıllıspıe, New York 1981, s. 39-40; J. Vernet, "al-Madjrîț̂”, The Encyclopaedıa Of Islam, (EL ${ }^{2}$ ) (İng.), vol. VI, s. 1109-1110.

51 Josep Casulleras, Majrîtî: “Abû al-Qâsim Maslama ibn Ahmad al-Hâsib al-Faradî al-Majrîtî” The Biographical Encyclopedia of Astronomers, Vol. II, Editor-in-Chief Thomas Hockey, Springer, New York 2007, s. 728.

${ }^{52}$ Fuat Sezgin, a.g.e., VII, s. 194-195; Fuat Sezgin, a.g.e., IV, s. 294-298; Ömer Mahir Alper, "Mecrîtî", DİA, c. XXVIII, TDV Yayınları, Ankara 2003, s. 278-279. 


\section{Sonuç}

“Ortaçağ Arap-İslam Devletlerinde İlm-i Nücûm ve Müneccimlik” adı altında ele aldığımız bu makalemizde görüldüğü üzere İslam Peygamberi $\mathrm{Hz}$. Muhammed tarafindan kesin bir dile yasaklanmasına karşın ilm-i nücûm ve müneccimlik müessesesi Arap-İslam devletlerinde görülmüştür. Emeviler döneminde (661-750) tercüme hareketleri ile kendini gösteren ilm-i nücûm hareketleri ve müneccimlik müessesesi Abbasiler döneminde (751258) saray teşkilatında zirve yapmaya başlamıştır. Fatımiler ve Endülüs Emevileri de bu çemberin dışında kalmamışlardır. Tabii doğal olarak aklımıza "İslam'ın ilk yıllarında İslam Peygamberi $\mathrm{Hz}$. Muhammed tarafindan yasaklandiğı için devlet ve toplum düzeyinde karşıllk bulamayan ilm- $i$ nücûm ve müneccimlik müessesesinin nasıl oluyor da yine halkını Müslümanların oluşturduğu ve siyasi bir organizasyon olan Emeviler, Abbasiler, Fatımiler ve Endülüs Emevileri dönemlerinde saray teşkilatında örneklerine rastlanabiliyor?" şeklinde bir soru geliyor.

$\mathrm{Bu}$ sorunun cevabını bir sebeple veya kesin bir cevapla açıklamak doğru değildir. Ancak ilm-i nücûm ve müneccimlik müessesesinin Arap-İslam devletlerinde ortaya çıkışı; İslamiyet'in ilk yıllarında haklı gerekçelerle eski Arap geleneklerini bir tarafa bırakarak yeni bir toplum oluşturma çabası sırasında veya Müslümanlığın yayılmaya başladığı sırada yaşanan heyecanın Hz. Muhammed'in ölümünden sonra azalmasi; Arap-İslam toplumunun $\mathrm{Hz}$. Muhammed ve Dört Halife dönemlerinden sonra iktidarı ele geçiren Emeviler döneminde (661-750) Cahiliye devri geleneklerine yeniden sicak bakması; müneccimlik, falcılık ve büyücülügün Arap toplumunun cahiliye döneminden beri bilinmesi; Abbasiler döneminde (750-1258), özellikle batı ve doğu kaynaklarının Arapçaya çevrilmesi ile Halife Me'mun döneminde (813-833) İslam Rönesansı'nın yaşanması neticesinde ilm-i nücûma ve müneccimliğe hümanist bir yaklaşımla bakılması vb. sebeplerle açıklanabilir. Hatta İlm-i nücûm ve müneccimlik müessesesinin Arapİslam devletlerinde ortaya çıkışını bu sebeplerin dışında başka sebeplerle de açıklanabilir. Fakat amacımız ilm-i nücûm ve müneccimlik müessesesinin Arap-İslam devletlerinde ortaya çıkışı sebepleri üzerinde durmak değil, bu ilmin ve müessesenin Arap-İslam devletlerinde işlevsel olarak kullanıldığını göstermektir. Bu açıdan ilm-i nücûm ve müneccimlik müessesesinin Arapİslam devletlerinde ortaya çıkış nedenleri üzerinde fazlaca durmayı gerekli bulmuyoruz. Temelde Arap-İslam devletlerinde ilm-i nücûm ve müneccimlik müessesesinin görülmesini mütalaa etmek daha sağlıklı bir yaklaşım olacaktır.

İlm-i nücûm ve müneccimlik müessesesinin Arap-İslam devletlerinde bulunması İslami bir zayıflık değildir; bu insani bir zafiyettir. Zira insanoğlunun geleceğini merak etmesi, savaşta ve barışta siyasi sorumluluk doğurabilecek bir hamle yapmayı kolay kolay göğüsleyememesi ve en asgari düzeyde kendi talihini öğrenme arzusu taşıması doğal olarak ilm-i nücûm ve müneccimlik müessesesinin önceki devletlerde olduğu, sonraki devletlerle de olacağ gibi Arap-İslam devletlerinde görülmesine vesile olmuştur. Arap-İslam devletlerinde tahta çıkan siyasi iradenin de bir insan olduğunu unutmamak gerekir. Bu açıdan bakıldığında tahta çıkan Arap-İslam devleti hükümdarlarının ilm-i Nücûma ilgi duyması ve yanında -sarayda- müneccim bulundurması gayet doğal olmalıdır. Bazı hükümdarlar zaman zaman kendilerini bu ilme ve müneccimlere kaptırırken bazen de bu ilme itimat etmeyen ve müneccimlere sıcak bakmayan hükümdarlara da rastlanmıştır.

Netice olarak makalemizi şu şekilde hülasa edebiliriz; Ortaçağ Arap-İslam Devletlerinde İlm-i Nücûm ve müneccimlik müessesine en çok Abbasiler önem vermişlerdir. Yukarıda da değindiğimiz gibi Abbasiler döneminde (750-1258) sarayda birçok müneccime rastlanmaktadır. Nitekim sarayda birden çok müneccimin bulunmasından dolayı baş müneccimlik müessesesi tesis edilmiştir. Abbasilerin ikinci halifesi Mansur ve sonraki dönemlerde tahta geçen Me'mun dönemlerinde de baş müneccimlik müessesesine rastlanmaktadır. Fakat Fatımiler ve Endülüs

\section{History Studies}


Emevileri dönemlerinde ise ilm-i nücûm ve müneccimlik müessesine rastlanmasına karşın, bu ilmin ve müneccimlik müessesesinin öneminin Abbasiler döneminde olduğu kadar olmadığ1 söylenebilir.

\section{Kaynakça}

ALPER, Ömer Mahir, "Mecrît̂̂”, DİA, c. XXVIII, TDV Yayınları, Ankara 2003, s. 278-279.

AYDIN, Cengiz, "Ebû Sehl b. Nevbaht” , DİA, c. X, TDV Yayınları, İstanbul 1994, s. $227-$ 228.

AYDÜZ, Salim, "Osmanlı Devleti'nde Müneccimbaş1lı", Osmanlı Bilim Araştırmaları Dergisi, Sayı:1, İstanbul 1955, s. 159-207. , İstanbul Muvakkithaneleri ve Muvakkitleri, İBB Yayınları, İstanbul 2009.

BAKKAL, Ali, "İslâm Astronomi Tarihinde İbn Rüşd: Büyük İslâm Filozofu İbn-i Rüşd", Diyanet Dergisi, c. XLVIII, Sa. 3, Temmuz-Ağustos-Eylül 2013, s. 195-208.

Harran Okulu, Şanlıurfa Valiliği İl Kültür ve Turizm Müdürlüğü Yayınları, İstanbul 2006.

BELENKIYY, Ari,"Mâshâ'allâh ibn Atharî (Sâriya)", The Biographical Encyclopedia of Astronomers, Vol. II, Editor-in-Chief Thomas Hockey, Springer, New York 2007, s. 740-741.

BRENTJES, Sonja,"Sanad ibn "Alî: Abû al-Tayyib Sanad ibn "Alî al-Yahûdî", The Biographical Encyclopedia of Astronomers, Vol. II, Editor-in-Chief Thomas Hockey, Springer, New York 2007, s. 1011.

CASULLERAS, Josep, "Majrîtî: Abû al-Qâsim Maslama ibn Ahmad al-Hâsib al-Faradî alMajrîtî" The Biographical Encyclopedia of Astronomers, Vol. II, Editor-in-Chief Thomas Hockey, Springer, New York 2007, s. 727-728.

"Banû Mûsâ", The Biographical Encyclopedia of Astronomers, Vol. I, Editor-in-Chief Thomas Hockey, Springer, New York 2007, s. 92-94.

ÇEÇEN, Kazım-BİR, Atilla, "Beni Musa”, DIAA, c. V, TDV Yayınları, İstanbul 1992, s. 450451.

ÇELİK, Aydın, Fatımiler Döneminde Kahire Şehri, Fırat Üniversitesi Basımevi, Elazığ 2008.

DİZER, Muammer, “Ebu Ma'şer el-Belhi”, DİA, c. X, TDV Yayınları, İstanbul 1994, s. $182-$ 184.

EL FERGÂNÎ, Cevami İlm En-Nucüm ve Usul-El Harekât (Astronominin Özeti ve Gögün Hareketlerinin Esaslart), (Çev: Yavuz Unat), T.C. Kültür ve Turizm Bakanlığ Yayınları, Ankara 2012.

FAHD Toufic, La Divination Arabe, Universite de Strasbourg, Leiden 1966. s. $105-108$

"Nudjûm", The Encyclopaedia Of Islam, (EL $L^{2)}$ (İng.), vol. VIII, Leiden 1995,

FEHD, Tevfik, “İlm-i Ahkâm-1 Nücum”, DIAA, c. XXII, TDV Yayınları, İstanbul 2000, s. 124126.

GOLDSTEIN, B.R., "Ibn Yûnus”, The Encyclopaedıa Of Islam, (EL $\left.{ }^{2}\right)$ (İng.), Vol. III, 969-970.

\section{History Studies}


HILL, Donald, A History Of Engineering in Classical And Medieval Times, Routledge, London-Newyork 2007.

IBN HALLIKAN, Vefeyatü'l-A'yan, c. II/III, Translated Baron Mac-Guckin de Slane, Mektebetu Lübnan (Librairie du Liban), Beyrut 1970.

İBN EBİ USAYBİA, Uyûnu'l-Enbâ' Fi Tabakati'l-Atibbâ, c. I, Kahire 1956.

İBN HACER el-ASKALANÎ, Lisânü'l-Mîzân, c. IV, Beyrut 1390/1971.

İBN-İ HALDÛN, Mukaddime, c. I, Çev: Halil Kendir, Yeni Şafak Kültür Armağanı, İstanbul 2004.

İBNU'L-KIFTÎ, Târîhu'l-Hukemâ', nşr. Julius Lippert, Dieterich'sche Verlagsbuchhandlung, Leipzig 1903.

KASAK, Enn, Anclent Astrology As A Common Root For Sclence And Pseudo-Sclence, Folklore Vol. XV, Tartu 2000.

KÂTIP ÇELEBİ, Keşfu'z-Zunun, c. II, Arapçadan Tercüme Eden Rüştü Balcı, Tarih Vakfı Yurt Yayınları, İstanbul 2007. , Keşfu'z-Zunun, c. II, nşr. M. Şerafeddin Yaltkaya, Maarif Vekâleti, İstanbul 1943.

KING, David A., "Ibn Yûnus: Abû al-Hasan 'Alî ibn 'Abd al-Rahmân ibn Ahmad ibn Yûnus al-Sadafi”", The Biographical Encyclopedia of Astronomers, Vol. I, Editor-in-Chief Thomas Hockey, Springer, New York 2007, s. 573.

KUTLUER, İlhan, “TABERÎ, Ömer b. Ferruhân”, DİA, c. XXXIX, TDV Yayınları, İstanbul2009, s. 321-322.

MAKRİẐ, İttiazü'l-Hunefa bi-Ahbari'l-Eimmeti'l-Fatımiyyine'l-Hulefa, Thk. Cemaleddin eşŞeyyal, c. I. Kahire 1948.

MC GINNIS, Jon \& REISMAN, David C., Classical Arabic Philosophy: An Anthology of Sources, Hackett Publishing Company, Indianapolis/Cambridge 2007.

NALLINO, C. A., “Astroloji”, IA , c. I, MEB Yayınları, İstanbul 1978, s. 682-686.

NİZÂMÎ 'ARÛZÎ SEMERKANDÎ, Çehar Makale, Tashih: Muhammed Kazvinî ve Muhammed Muin, Tahran 1327. , Çehâr Makâle, Demavend Yayınları, İstanbul 2016.

ÖZDEMİR, Mehmet, "Hişâm II”, DIAA, c. XVIII, TDV Yayınları, İstanbul 1998, s. 146-147.

PINGREE, D., “Astronomy and Astrology in India and Iran”, ISIS, LIV, 1963, s. 241-242.

SÂİD EL-ENDELÜŜ̂, Tabakatü'l Ümem, Nşr. Louis Rizkullah Şeyho, el-Matbaatü'lKatolikiyye, Beyrut 1912.

, Tabakatü'l-Ümem, (Çev: Ramazan Şeşen), Türkiye Yazma eserleri Başkanlığı Yayınları, İstanbul 2014.

SALIBA, George, "The Role Of The Astrologer In Medieval Islamic Society", Bulletin D'études Orientales, T. 44, Sciences Occultes Et Islam, 1992, s. 45-67. 
SAMSÓ, Juilo, "Ibn al-Bannâ: Abû al-'Abbâs Aḥmad ibn Muhammad ibn 'Uthmân al-Azdî alMarrâkushî”, The Biographical Encyclopedia of Astronomers, Vol. I, Editor-in-Chief Thomas Hockey, Springer, New York 2007, s. 551-552.

, "Ibn Ishâq: Abû al-'Abbâs ibn Ishâq al-Tamîmî al-Tûnisî”, The Biographical Encyclopedia of Astronomers, Vol. I, Editor-in-Chief Thomas Hockey, Springer, New York 2007, s. 558-559.

SEZGİN, Fuat, Geschichte Des Arabıschen Schrifttums (GAS), IV, Institut für Geschichte der Naturwissenschaften, Leiden 1971.

, Geschichte Des Arabıschen Schrıfttums (GAS), VII, Institut für Geschichte der Naturwissenschaften, Leiden 1979.

, İslam'da Bilim ve Teknik, c. I, T.C. Kültür ve Turizm Bakanlığı Yayınları, İstanbul 2008.

ŞEMSEDDÎN es-ŞEHREZURÎ, Nüzhetü'l-Ervâh, Çev: Eşref Altaş, Türkiye Yazma Eserler Kurumu Başkanlığı, İstanbul 2015.

TEZ, Zeki, Ortaçă̆ İslam Dünyasında Bilim ve Teknik, Dicle Üniversitesi Fen-Edebiyat Fakültesi Yayınları, Diyarbakır 1991.

UNAT, Yavuz, Yahya b. Ebu Mansur el-Müneccim”, DIA, c. XLIII, TDV Yayınları, İstanbul 2013, s. 242.

VAN DALEN, Benno, "Yahyâ ibn Abî Mansûr: Abû 'Alî Yahyâ ibn Abî Mansûr alMunajjim", The Biographical Encyclopedia of Astronomers, Vol. II, Editor-in-Chief Thomas Hockey, Springer, New York 2007, s. 1249-1250.

VERNET, J., “al-Majrîtî”, Dictıonary Of Scıentific Blography, Vol. IX, Editor in Chıef: Charles Coulston Gillispie, New York 1981, s. 39-40. 1110. , "al-Madjrîṭ̂", The Encyclopaedıa Of Islam, (EL $\left.{ }^{2}\right)$ (İng.), Vol. VI, s. 1109-

YAMAMOTO, Keiji, “Abû Ma'shar Ja'far ibn Muhammad ibn 'Umar al-Balkhi”, The Biographical Encyclopedia of Astronomers, Vol. I, Editor-in-Chief Thomas Hockey, Springer, New York 2007, s. 11.

ZAHİREDDIN ALİ BİN el-BEYHAKÎ, İtmam Tetimmat Şivan el-Hikme, Lahor 1351.

ZEKİ, Salih, Âsâr-ı Bâkiye, Çev: Melek Dosay Gökdoğan-Remzi Demir-Mutlu Kılıç, c. III, Babil Yayın Dağıtım, Ankara 2004. 